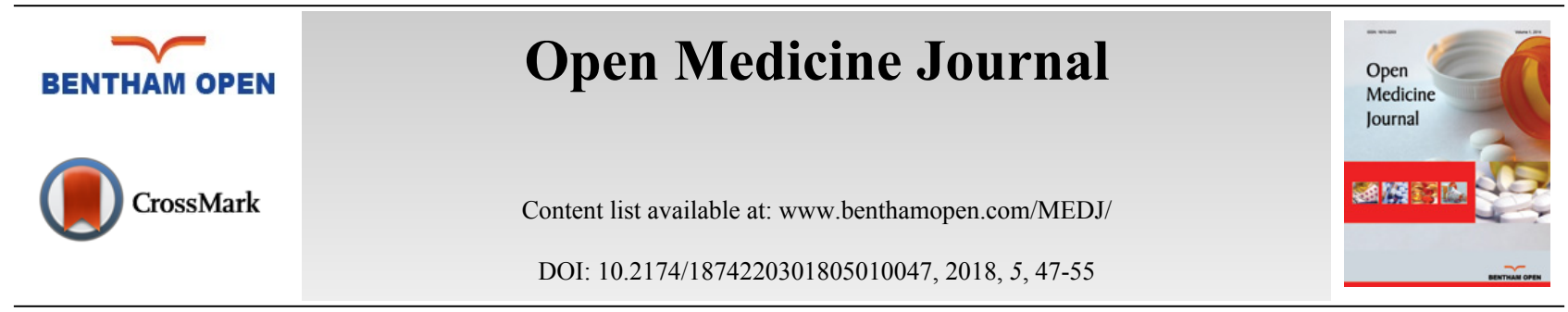

RESEARCH ARTICLE

\title{
Standardization of Dhatryadi Ghrita: A Herbal Ghee Based Ayurvedic Medicinal Preparation
}

\author{
Rashmi Saxena $\mathrm{Pal}^{1, *}$ and Amrita Mishra ${ }^{2}$ \\ ${ }^{\text {I}}$ Pharmacy Department, Pranveer Singh Institute of Technology, Kanpur, India \\ ${ }^{2}$ School of Pharmaceutical Sciences, IFTM University, Moradabad, India
}

Received: June 2, 2018

Revised: August 10, 2018

Accepted: August 15, 2018

\begin{abstract}
:
Background:

In the current time, there is a need to thoroughly examine the process of systematic research methodology and to provide genuine findings to provide the reference for further investigations of traditional herbal medicines, which are beneficial for various disorders.
\end{abstract}

\section{Objectives:}

To standardize Dhatryadi Ghrita on various parameters, in order to assure its safety and efficacy on various grounds.

\section{Methods:}

The Ghrita was analyzed for its organoleptic, physico-chemical features and screened for its phyto-constituents as well as its chromatographic analysis.

\section{Results:}

The physicochemical standards would serve as a preliminary test for the standardization of the formulation, which helps to lay standards for further use as reference for the quality control/quality assurance laboratory of a Pharmaceutical house.

\section{Conclusion:}

The improvement of analytical methodologies can serve as a specific basis for research in herbal drug technology, thereby, facilitating the producers and researchers to set quality standards as well as parameters, so as to fulfill the requirements of regulatory bodies for the establishment of therapeutic efficacy, safety and purity of herbal drugs. The obtained values can be adopted to lay down new pharmacopoeial standards to be followed in its preparation with batch to batch consistency.

Keywords: Dhatryadi, Ghrita, Standardization, Parameters, Herbal ghee, Ayurvedic medicine.

\section{INTRODUCTION}

There are various Ayurvedic, herbal based dosage forms, which are properly mentioned in texts as Ayurvedic Pharmacopoeia and formulary like vati (tablets), churna (powders), asava and arishta (self-generated alcohol based elixir), snehakalpa (medicated oil), Ghrita (medicated ghee)etc. for the treatment of different diseases. Vata, Pitta and Kapha; the three fundamental energies or principles which govern the function of our bodies on the physical and emotional level constitute tridosh. They should be well balanced for proper health of the mind and soul. Vata dosh if disturbed causes 80 types of ailments whereas Pitta imbalance is responsible for 40 types of diseases [1]. Ghritas are lipid based ayurvedic formulations or medicated ghee, in which ghee is boiled with the decoction or the paste of the

\footnotetext{
* Address correspondence to this author at the Department of Pharmacy, PSIT Kanpur, Kanpur, U.P, India; Tel: 9129826459; E-mail: rashmisaxenapal@gmail.com
} 
crude drug, so that the active constituents of drugs get transferred into ghritas [2]. In Ayurveda, Ghee is known to be the healthiest option of edible fat, when the nutritive value is being considered, as it possesses beneficial properties and facilitate the positive effect of herbal drugs added to it in the preparation of medicated ghee [3]. These lipid based polyherbal formulations have the capacity to cross blood brain barrier and show beneficial effects on brain tissue. Dhatryadi Ghrita is an ayurvedic medicine, also known as herbal ghee, where ghee acts as the base and is recommended for the treatment of various CNS disorders. Its main ingredient is Dhatri (Emblica officinalis) [4]. It was a novel introduction of incorporation of additional properties along with coloration, purification and composition of ghrita. Drug administered in the form of ghee are quickly digested and absorbed. It is also able to reach the most distant areas of body like the CNS. A water soluble drug gets distributed in the extracellular spaces, but not to the intracellular ones. Whereas the lipid solubilized drugs are rapidly distributed throughout the intra and extracellular spaces [5].

In consideration of many harmful effects of chemical based agents, there is a growing need to adopt research methodology and to provide scientific grounds for the traditional plant based medicines that are supposed to be effective in various disorders. The first step for scientifically based research is to provide quality standardization of drug. With this referencing as background the present study was undertaken to ascertain the authenticity of all the ingredients of Dhatryadi Ghrita and presence of components as recommended through pharmacognostical study and physicochemical analysis of Dhatryadi Ghrita $[6,7]$. The Ghrita was prepared from the purified as well as standardized crude herbal constituents as per the method and the formula given in the Ayurvedic formulary. It was then standardized on various parameters in order to assure its safety and efficacy on various grounds. Standardization is beneficial for laying a solid foundation, with the help of new technologies to share, enhance and improve existing practices. Standardization is also helpful in building the standards for assisting Governments, Administrations, Regulators and also supports the development of new policy initiatives [8].

\section{COLLECTION OF RAW DRUG}

Raw drugs were collected from rural farms of Kanpur Dehat at the time of preparation of drug. All these were identified and authenticated from NBRI, Lucknow. Ghrita (Cow's ghee) was procured from Khadi Gramodyoga Bhandar, Kanpur and Dhatryadi Ghrita was prepared in Pharmacognosy lab of PSIT, Kanpur. The physical impurities were removed from the herbal drugs, and they were dried and made into a coarse powder to use for the pharmacognostical study. Ghrita (Table 1) was prepared as per the classical reference. A physicochemical analysis of the final product was carried out in the Pharmaceutical Chemistry Laboratory of the institute.

\section{METHOD OF PREPARATION OF DHATRYADI GHRITA}

After collecting all the ingredients of Dhatryadi Ghrita as mentioned in Table 1.The Ghrita was prepared according to the procedure mentioned in Ayurvedic formulary. In which the crude drugs as fresh fruits of Dhatri and Kushmanda, fresh tuberous roots of Vidari and Iksu, fresh tuberous roots of Shatavari were taken to extract out fresh juice from them, after washing and shade drying of the crude drugs. Then the other herbs as stolons and roots of Liquorice and heartwood powder of white sandalwood were cleaned, dried and powdered. Resin was added to the above powdered ingredients in order to sweeten the formulation, then sufficient quantity of purified water was added to make homogenous composition. After this, Go-Ghrita and milk was added in equal quantity as cited in Table 1, while heating with continuous stirring for about 3 hours. It was then kept overnight and was filtered next day while hot and cooled afterwards. After cooling, sugar was added and stirred vigorously.

Table 1. Contents used in Dhatryadi Ghrita.

\begin{tabular}{|c|c|c|c|c|}
\hline S.No & Ingredient & Botanical Name & Part Used & Amount Used \\
\hline 1. & Amalki & Emblica officinalis & Fresh fruits & $768 \mathrm{ml}$ \\
\hline 2. & Vidari & Pueraria tuberosa & Tuberous roots & $768 \mathrm{ml}$ \\
\hline 3. & Iksu & Saccharum officinarum & Dried stem & $768 \mathrm{ml}$ \\
\hline 4. & Shatavari & Asparagus racemosus & Tuberous roots & $768 \mathrm{ml}$ \\
\hline 5. & Kusmanda & Beninca sahispida & Dried fruits & $768 \mathrm{ml}$ \\
\hline 6. & Draksha & Vitis vinifera & Dried fruits & $24 \mathrm{gms}$ \\
\hline 7. & Yasti & Glycyrrhiza glabra & Stolon and root & $24 \mathrm{gms}$ \\
\hline 8. & Shwet Chandan & Santalum album & Heart wood & $24 \mathrm{gms}$ \\
\hline 9. & Go ghrita & Butyrum deparatum & - & $768 \mathrm{ml}$ \\
\hline 10. & Go Dugdha & Ksira & - & $768 \mathrm{ml}$ \\
\hline
\end{tabular}


(Table 1) contd.....

(Table 1) contd.....
\begin{tabular}{|c|c|c|c|c|}
\hline S.No & Ingredient & Botanical Name & Part Used & Amount Used \\
\hline 11. & Sugar & Khanda & - \\
\hline
\end{tabular}

\section{ORGANOLEPTIC STUDY}

Organoleptic characteristics for various sensory characters like color, taste, odouretc was carefully noted down [9 11] as illustrated in Table $\mathbf{2}$. The raw drugs and powders were separately studied by organoleptic and morphological characters like Rupa(Color), Rasa (Taste), Gandha (Odor), Sparsha (Touch), and so on.

Table 2. Organoleptic Parameters of Dhatryadi Ghrita.

\begin{tabular}{|c|c|c|}
\hline $\mathbf{1 .}$ & Colour & Muddy-Brown \\
\hline $\mathbf{2 .}$ & Odour & Ghee like \\
\hline $\mathbf{3 .}$ & Taste & Sweet \\
\hline $\mathbf{4 .}$ & Touch & Sticky \\
\hline $\mathbf{5 .}$ & Appearance & Coarse,viscous, semi-solid \\
\hline
\end{tabular}

\section{PHYSICOCHEMICAL ANALYSIS}

\subsection{Loss on Drying at $110^{\circ} \mathrm{C}$}

1. Place the weighed crucible with $5 \mathrm{gm}$ material in tilted lid position in the oven at $105^{\circ} \mathrm{C}$ for at least 2 hours.

2. Place the crucible in the desiccator by using tongs or gloves and allow cooling for at least 30 minutes.

3. It was taken out and weighed again and again at regular interval till the consistent weight was achieved. The percentage of difference was considered as loss on drying at that particular temperature.

Deterioration time of the plant material depends upon the amount of water present in plant material. If the water content is high, the plant can be easily deteriorated due to fungus [12].

\subsection{Refractive Index}

Abbe's refractometer is used to measure the refractive index of the given ghrita. Using a particular monochromatic light source, the apparatus is calibrated with water as the liquid. The micrometer screw is adjusted to focus the boundary between the bright and dark regions, then the refractometer scale is adjusted to place the cross wire of the telescope exactly on the boundary between the bright and dark regions. The same process is repeated after the equipment is calibrated. A drop of water was placed on the prism and the drive knob was adjusted in such a way that the boundary line intersects the separatrix exactly at the centre, and reading was noted.

Distilled water has been found to have a refractive index of 1.3325 at $25^{\circ} \mathrm{C}$. The difference between the reading and 1.3325 gives the error of the instrument. If the reading is less than 1.3325 , the error is minus (-) then the correction is plus (+) if the reading is more, the error is plus $(+)$ and the correction is minus (-). Refractive index of Ghrita was determined using 1 drop of the sample. All fats are composed of various types of fatty acids and their derivatives, such as esters in various ratios. With changes of temperature or any other ingredients, the basic constitution of particular fat varies. Such variation may be due to the any impurities added due to any reason. Refractive index varies with temperature and wavelength [13].

\subsection{Specific Gravity}

Specific gravity bottle was cleaned and shaken with acetone and then with ether. Bottle was dried and weight was noted down. The specific gravity bottle was filled with the ghrita and weight was noted. The procedure was repeated using distilled water in place of Ghrita. The weight of the empty bottle with stopper was recorded. About 10 gms of Ghrita was taken, which was later cooled in a desiccator. The Ghrita was then transferred into the bottle. Then the weight of the bottle and Ghrita was noted. The bottle was again filled completely with $10 \mathrm{ml}$ distilled water. The stopper was placed and the bottle was kept under constant temperature. The bottle was then taken outside, wiped clean, dried and noted. Now determine the weight of the bottle and the contents. The bottle was emptied and thoroughly cleaned, then filled with distilled water and weighed.

The weight of lipid material is affected by the factors such as basic constitution, dissolved constituents used in the 
preparation of formulation, or any other compound or excipient, which may be used during the process etc. In case of fat, it may also change with thermal fluctuations [14].

\subsection{Rancidity Test}

$1 \mathrm{ml}$ of melted ghrita was mixed with $1 \mathrm{ml}$ of conc. $\mathrm{HCl}$ and $1 \mathrm{ml}$ of $1 \%$ solution of phloroglucinol in diethyl ether and then mixed thoroughly with the fat acid mixture. A pink color indicates that the fat is slightly oxidized while the red color indicates that the fat is definitely oxidized $[15,16]$.

\subsection{Acid Value}

$10 \mathrm{~g}$ of Ghrita was taken in a conical flask. To it was added $50 \mathrm{ml}$ of acid free alcohol-ether mixture $(25+25 \mathrm{ml})$ previously neutralized by the addition of $1 \mathrm{ml}$ of Phenolphthalein solution and titrated against $0.1 \mathrm{~N}$ potassium hydroxide solution. End point is figured out with the appearance of pale pink colour which persists for 15 seconds.

The acidity is affected with the process of oxidation as triglycerides get converted in to fatty acids and glycerol. Liberation of fatty acid is the outcome of hydrolysis, thermal effects and lipolytic enzymes as lipase. So, of acid value varies linearly with rancidity. In present work, acid value of Ghrita was found to be below 2 which indicated better quality [17].

\subsection{Saponification Value}

1. $2 \mathrm{~g}$ of fat in a tared beaker was weighed and dissolved in about $3 \mathrm{ml}$ of the fat solvent (ethanol /ether mixture).

2. The contents of the beaker were quantitatively transferred three times with a further $7 \mathrm{ml}$ of the solvent.

3. $25 \mathrm{ml}$ of $0.5 \mathrm{~N}$ alcoholic $\mathrm{KOH}$ was added and mixed well, which was attached to a reflux condenser.

4. Another reflux condenser as the blank with all other reagents was present except the fat was set.

5. Both the flasks were placed in a boiling water bath for 30 minutes.

6. The flask was cooled at room temperature.

7. Now added phenolphthalein indicator to both the flasks and titrated with $0.5 \mathrm{~N} \mathrm{HCl}$.

8. Noted down the endpoint of blank and test .

9. The difference between the blank and test reading gives the number of millilitres of $0.5 \mathrm{~N} \mathrm{KOH}$ required to saponify $1 \mathrm{~g}$ of fat.

Saponification value or number of fat $=\mathrm{mg}$ of $\mathrm{KOH}$ consumed by $1 \mathrm{~g}$ of fat.

The long chain fatty acids present in fats have a low saponification value because they have a relatively fewer number of carboxylic functional groups per unit mass of the fat, when compared to short chain fatty acids. Mediumchain triglycerides are considered as good biologically inert source of energy that is easy for the human body to metabolize. They passively diffuse from the GI tract to the portal system without requirement for modification like long-chain fatty acids or very-long-chain fatty acids [18].

\subsection{Iodine Value}

$10 \mathrm{ml}$ of fat sample was pipetted out and dissolved in chloroform to an iodination flask labelled as "TEST". 20ml of Iodine Monochloride reagent was added into the flask. The contents in the flask are thoroughly mixed. Then the flask is allowed to stand for half an hour in the dark.

Set up a BLANK in another iodination flask by adding $10 \mathrm{ml}$ Chloroform to the flask.

Add to the BLANK, $20 \mathrm{ml}$ of Iodine Monochloride reagent and the contents were mixed in the flask thoroughly. The BLANK was incubated in dark for 30 minutes. Meanwhile, the TEST was taken out from incubation after 30 minutes and $10 \mathrm{ml}$ of potassium iodide solution was added into the flask.

The stopper and the sides of the flask was rinsed using $50 \mathrm{ml}$ distilled water. The "TEST" against standardized sodium thiosulphate solution was titrated until a pale straw colour is observed. About $1 \mathrm{ml}$ starch indicator was added into the contents in the flask, and a purple colour is observed. The titration is continued until the color of the solution in the flask turns colourless. The disappearance of the blue colour is recorded as the end point of the titration.

Heat increases the dissociation and unsaturation of the molecules of compound [19]. Physicochemical analysis such 
as loss on drying at $110^{\circ} \mathrm{C}$, water soluble extractive, Total ash, Acid insoluble ash, Alcohol soluble extract (Table 3). Specific gravity and refractive index tests were carried out [20-22].

Table 3. Physico-chemical parameters of Dhatryadi Ghrita.

\begin{tabular}{|c|c|c|}
\hline S.No & Parameters & Results \\
\hline $\mathbf{1 .}$ & Refractive index & 1.243 \\
\hline $\mathbf{2 .}$ & Specific gravity & 0.85 \\
\hline $\mathbf{3 .}$ & Rancidity test & Fat is not oxidised \\
\hline $\mathbf{4 .}$ & Acid value & 1.5 \\
\hline $\mathbf{5 .}$ & Saponification value & 95 \\
\hline $\mathbf{6 .}$ & Iodine value & 65 \\
\hline $\mathbf{7 .}$ & Loss on drying & 0.15 \\
\hline
\end{tabular}

\section{PHYTOCHEMICAL SCREENING: QUALITATIVE TESTS}

\subsection{Phytochemical Qualitative Analysis}

The plant extracts in ethanolic solutions were assessed for the existence of the phytochemical analysis by using the following standard methods [23 - 26]. Tests for different active principles Dhatryadi Ghrita was subjected to qualitative tests to detect the various phytoconstituents as- Carbohydrates, lipids, alkaloids, terpenoids, tannins, proteins etc. Materials were dissolved separately in $5 \mathrm{ml}$ of alcohol and filtered; the filtrates were used to test the presence of carbohydrates [27].

\subsection{Benedict's Test}

Filtrate was subjected to treatment with Benedict reagent and then heated on water bath, formation of an orange red precipitate indicates the presence of reducing sugar.

\subsection{Detection of Protein and Amino Acids as in Millon's Test}

The alcoholic extracts were treated with $2 \mathrm{ml}$ of millon's reagent. The formation of white precipitate which turns to red upon heating indicates the presence of proteins.

\subsection{Detection of Alkaloids}

The extract was dissolved individually in dilute HCL and filtered. The filtrates were treated with alkaloid reagent.

\subsubsection{Hagers Test}

Filtrates were treated with Hagers reagent (solution of picric acid) formation of yellow precipitate indicates the presence of alkaloids.

\subsubsection{Foam Test}

To the 5 gm drug powder, water was added in the test tube and shaken for 5 minutes. Formation of persistent froth confirms the presence of saponin glycosides.

\subsection{Detection of Phenol and Tannins (Ferric Chloride Test)}

The alcoholic extract was treated with few drops of neutral ferric chloride solution. The appearance of either of green, orange, blue or purple- red color indicates the positive test.

\subsection{Detection of Terpenoids}

$2 \mathrm{ml}$ of the alcoholic extract was dissolved in $2 \mathrm{ml}$ of $\mathrm{CHCl} 3$ and evaporated to dryness. $2 \mathrm{ml}$ of conc. $\mathrm{H} 2 \mathrm{SO} 4 \mathrm{was}$ then added and heated for about 2 minutes. Development of a grayish color indicates the presence of terpenoids.

\subsection{Thin Layer Chromatography}

Thin layer chromatography was performed for ghrita using solvent Toluene and Ethyl acetate in 6:4 ratio [28 - 30]. 
Table 4. Phytochemical screening parameters of Dhatryadi Ghrita.

\begin{tabular}{|c|c|c|}
\hline S.No & Reagent & Result \\
\hline 1. & Foam test & $+\mathrm{ve}$ \\
\hline 2. & Reducing sugars & $+\mathrm{ve}$ \\
\hline 3. & Terpenoids & $+\mathrm{ve}$ \\
\hline 4. & Alkaloids & $+\mathrm{ve}$ \\
\hline 5. & Tannins & $+\mathrm{ve}$ \\
\hline 6. & Proteins & $+\mathrm{ve}$ \\
\hline
\end{tabular}

TLC profile of unsaponifiable matter, the TLC profile of unsaponifiable matter of the sample (Fig. 1) showed two prominent spots at Rf 0.4 (blue), 0.86 (blue). Thin layer chromatography profile of Ghrita (Hexane Extract) was developed by using Benzene and Ethyl acetate in 9:1 ratio as solvent system and the plate were visualized in UV chamber at long wavelength $(366 \mathrm{~nm})$. The stationary phase is applied onto the plate uniformly and then allowed to dry and stabilize. These days, however, ready-made plates are preferred.

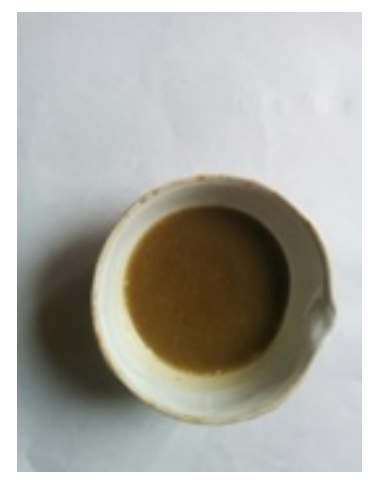

Fig. (1). Prepared Dhatryadi ghrita.

With a pencil, a thin mark is made at the bottom of the plate to apply the sample spots. Then, samples solutions are applied on the spots marked on the line in equal distances. The mobile phase is poured into the TLC chamber to a leveled few centimeters above the chamber bottom. A moistened filter paper in mobile phase is placed on the inner wall of the chamber to maintain equal humidity (and also thereby avoids edge effect this way). Now, the plate prepared with sample spotting is placed in TLC chamber so that the side of the plate with the sample line is facing the mobile phase. Then the chamber is closed with a lid. The plate is then immersed, such that the sample spots are well above the level of mobile phase for development. Allow sufficient time for the development of spots. Then the plates are removed and allowed to dry. The sample spots can now be seen in a suitable UV light chamber, or any other methods as recommended for the said sample. The $\mathrm{Rf}$ of spots exhibited was measured using scale.

\section{RESULTS AND DISCUSSIONS}

Organoleptic evaluation was performed for coarse powders and crude drugs. (Observations of organoleptic analysis are tabulated in Table 2). Raw herbs were authenticated and analyzed before processing because good quality products mainly dependent upon genuine raw materials. The colour of Ghrita is muddy brown due to the presence of contents like sugarcane juice, resins, shwet chandana etc. Since the base is go-ghrita, the odour is ghee like. Taste is sweet due to the addition of sweeteners such as powdered sugar and resins. As it is a semi-solid preparation made in ghee, it is viscous and sticky. It is coarse in appearance due to the addition of coarsely powdered crude drugs. Physicochemical analysis: Results of physicochemical analysis of Dhatryadi ghrita are detailed in Table 3. Loss on drying, Specific gravity, and Refractive index, are in normal range. If Saponification value is more than normal range, it indicates lower molecular saturated fatty acids. Higher the iodine value, the less stable will be Ghrita and the more susceptible it is to oxidation and free radical production. High iodine value Ghritas are prone to oxidation and polymerization and the sample becomes rancid, which decreases the shelf life and stability of the product. If acid value is more, then chances of photo-oxidation and rancidity are more. The obtained values of these tests were found within normal limits in Dhatryadi Ghrita, which indicate good quality of product. In addition, no rancidity was found in the finished product. The refractive index was 1.243 . The specific gravity of the sample was 0.851 , which was closer to plain Ghrita, for which it 
was 0.9 , showing that the sample was not too dense. The acid value was $1.5 \mathrm{w} / \mathrm{v}$, indicating the amount of free fatty acid present in the Ghrita. The saponification value was found to be $95 \mathrm{w} / \mathrm{v}$. It gave an idea of the molecular weight of an oil/fat, and the oil contained a long chain of fatty acids. The observed iodine value for the Ghrita was $65 \mathrm{w} / \mathrm{v}$, which indicated the consumption of the iodine molecules by free fatty acids. Phytochemical screening (Table 4): Ghrita showed the presence of glycosides, mainly in the form of saponin glycosides as glycyrrhizin etc. from liquorice which is confirmed by the foam test. Due to presence of Amla, it gives positive test for the presence of tannins. Addition of shwet Chandan enhances the terpenoids in the formulation and also provides soothing odor to the formulation. Presence of reducing sugars is because of the presence of Iksu and Shatavari in the Ghrita. Addition of resins and sugars also contributes towards it. Traces of alkaloids as well as amino-acids is also observed while screening the formulation for the presence of phyto-constituents. Amino acids are likely due to the addition of cow milk to the Ghrita.

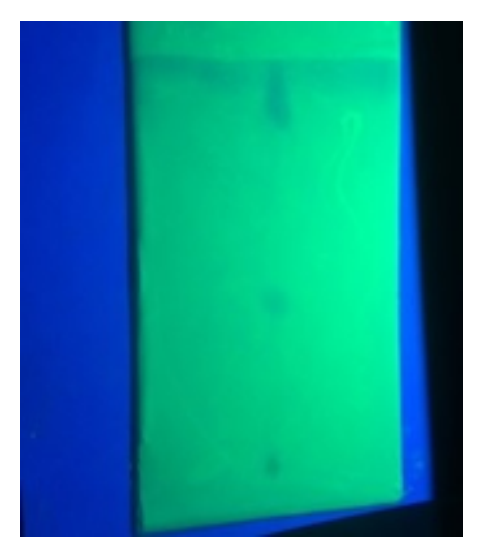

Fig. (2). TLC of Ghrita.

TLC: The findings of TLC, which is mainly performed for the confirmation of the phytoconstituents present sounds similar as mentioned in the Ayurvedic Pharmacopoeia, which mentions the same solvent system in the same ratio. It shows the presence of two major components in the Ghrita, which are soluble in non-polar solvent as hexane. The selection of solvent system signifies the increased non-polarity in order to separate the constituents of Ghrita, which is a lipid based preparation. The Rf value and the colour of the spots are also approximately same. It can be assumed that it may be due to the constituent of Kushmanda fruit juic, which is used to synthesize the formulation Fig. (2).

\section{CONCLUSION}

Despite the advent of modern technology in standardization of Ayurvedic formulations, only the data on a few of them are available. With the above standardization procedures, strictly through the standard guidelines, we get substantial information for proper identification of the phytoconstituents and their types. The advancement of analytical techniques can serve as a specific tool in herbal drug research, thereby, allowing the manufacturers to set quality standards and specifications so as to seek marketing approval from regulatory authorities for therapeutic efficacy, safety and shelf- life of herbal drugs. The purpose of standardization of medicinal plants is obviously to ensure therapeutic efficacy. Therefore, maintaining the quality of these plant products is an essential factor. Pharmacognostical study findings confirm the ingredients present in the Dhatryadi Ghrita. It is inferred that the formulation meets maximum qualitative standards based on physicochemical parameters. The results of this study may be used as the reference standard in further research undertakings of its kind. As not much work has been done on the Ghrita to explore its hidden potential. Pharmacognostical and phyto-chemical evaluation of Ghrita illustrated the specific characters of ingredients which were used in the preparation. Physico-chemical profile is an important parameter for quality control and assurance. In the present work, the obtained results were found within prescribed limits. For the first time, pharmaceutical and analytical profile of Dhatryadi Ghrita was established.

On the basis of the observations and results, obtained from the above methods adopted, this study may be used as standard in the further quality control researches. Pharmacognostical study findings confirm the ingredients present in the Dhatryadi Ghrita. 


\section{ETHICAL APPROVAL AND CONSENT TO PARTICIPATE}

Not applicable.

\section{HUMAN AND ANIMAL RIGHTS}

No animals/humans were used for the studies that are bases of this research

\section{CONSENT FOR PUBLICATION}

Not applicable.

\section{CONFLICT OF INTEREST}

The authors declare that there is no conflict of interest, financial or otherwise.

\section{ACKNOWLEDGEMENTS}

Declared none.

\section{REFERENCES}

[1] Tripathi B R, Charaka C. Hindi Commentary of Charaka Samhita:Varanasi:Chaukhamba Surbharati Prakashan, Sutrasthan-20(10); 2009.

[2] Government of India Ministry of Health and family welfare. $2^{\text {nd }}$ ed. New Delhi: Department of AYUSH 2003.

[3] Pal RS, Mishra A. A review on dhatryadi ghrita. Int J Res Ayurveda Pharm 2017; 8(2): 190-5. [http://dx.doi.org/10.7897/2277-4343.082111]

[4] ayurmedinfo.com, Dr JV Hebbar,2015 [cited 2017 March 29]. Available fromhttp://ayurmedinfo.com.

[5] Shastri A. Vidyotini T of Bhaishajya Ratnavali; $14^{\text {th }}$ edition. Chaukhamba Samskruta Samsthana, Kustharogadhikar, Varanasi: 2001.

[6] Anonymous. The Indian Pharmacopoeia. 4th edition. Govt. of India publication: New Delhi 1996.

[7] Amartya B, Krishanu D, Vikas S. A review on latest developments in the standardization of ayurvedic drugs. IJPRBS 2012; 1(3): 96-119.

[8] Pal RS, et al. Standardization of triphala churna: A polyherbal formulation. wjpls, 2016, 2(2):316-322.

[9] Wallis TE. Wallis TE, Text book of Pharmacognosy, $5^{\text {th }}$ Edition. CBS Publishers \& Distributors:New Delhi 2002.

[10] Rajpal V. Standardization of Botanicals. New Delhi: Eastern Publishers 2002; Vol. 1.

[11] Tandon N, Sharma M. Quality Standards of Indian Medicinal Plants. New Delhi: Indian Council of Medical Research 2010; Vol. 8.

[12] Ayurvedic Pharmacopoeia of India, Part - 1, Vol - iv, First Edition, Appendix 2 / 2.9 Government of India. Ministry of health and family welfare. Department of ayush: Delhi - 2011.

[13] Ayurvedic Pharmacopoeia of India, Part - 1,Vol - iv, First Edition, Appendix 3 / 1.2 Government of India. Ministry of health and family welfare. Department of ayush: Delhi - 2011.

[14] Ayurvedic Pharmacopoeia of India, Part - 1,Vol - iv, First Edition, Appendix 3 / 1.3 Government of India. Ministry of health and family welfare. Department of ayush: Delhi - 2011.

[15] Arya S, Ramanujam S, Vijayaraghavan P. Refractive index as an objective method for evaluation of rancidity in edible oils and fats. J Am Oil Chem Soc 1969; 46(1): 28-30. [http://dx.doi.org/10.1007/BF02632705]

[16] Dhurvey Y, Kawtikwar P, Sakarkar D. Evaluation of Physicochemical Properties of Cow Ghee before and after Hydrogenation. Int J Chemtech Res 2012; 4(1): 185-9.

[17] Ayurvedic Pharmacopoeia of India, Part - 1,Vol - iv, First Edition, Appendix 3 / 12 Government of India. Ministry of health and family welfare. Department of ayush: Delhi - 2011.

[18] Ayurvedic Pharmacopoeia of India, Part - 1,Vol - iv, First Edition, Appendix 3 / 10 Government of India. Ministry of health and family welfare. Department of ayush: Delhi - 2011.

[19] Ayurvedic Pharmacopoeia of India, Part - 1,Vol - iv, First Edition, Appendix 3 / 11 Government of India. Ministry of health and family welfare. Department of ayush: Delhi - 2011.

[20] Ayurvedic Pharmacopoeia of India Part 1,1 $1^{\text {st }}$ edition, published by Govt of India, The controller of publications civil lines, Delhi - 2011

[21] Lala PK. lab manuals of Pharmacognosy. $5^{\text {th }}$ edition., Calcutta; CSI Publishers and distributors, 1993.

[22] Khandelwal KR. Practical Pharmacognosy. Pune: Nirali Prakashani 2008.

[23] Debiyi OO, Sofowora FA. Pytochemical screening of medical plants. Iloyidia 1978; 3: 234-46. 
[24] Roopashree TS, Dang R, Rani RHS, Narendra C. Antibacterial activity of antipsoriatic herbs: Cassia tora, Momordica charantia and Calendula officinalis. Int J Appl Res Nat Prod 2008; 1(3): 20-8.

[25] Sofowora A. Phytochemical Screening of Medicinal Plants and Traditional Medicine in Africa. Ibadan, Nigeria: Spectrum Books Ltd 1993.

[26] Trease GE, Evans WC. "Phenols and phenolic glycosides," in Textbook of Pharmacognosy, vol. 12, pp. 343-383, Balliese, Tindall and Co Publishers, London, UK, 1989.

[27] Kokate CK, Purohit AP, Gokhale SB. Pharmacognosy. 42 ${ }^{\text {nd }}$ ed. Pune: NiraliPrakashan, 2008; 6.1: A1

[28] Egon Stahl, 1969 reprint, Thin Layer Chromatography, Springer publication, 2005124-241.

[29] Wagner H, Baldt S. Plant drug analysis - A Thin Layer Chromatography Atlas. $2^{\text {nd }}$ ed. Berlin, Heidelberg: Springer- Verlag 1996.

[30] Heftmann E. Chromatographya laboratory handbook of chromatographic and electrophoretic methods. $3^{\text {rd }}$ ed. Princeton MJ: Van Nostarand; 1975 .

\section{(C) 2018 Rashmi Saxena Pal.}

This is an open access article distributed under the terms of the Creative Commons Attribution 4.0 International Public License (CC-BY 4.0), a copy of which is available at: https://creativecommons.org/licenses/by/4.0/legalcode. This license permits unrestricted use, distribution, and reproduction in any medium, provided the original author and source are credited. 